\title{
Cardiovascular risk factors in a Roma sample population from Romania
}

\author{
EMMA WEISS ${ }^{1,2}$, CRISTINA JAPIE $^{1}$, ANA MARIA BALAHURA ${ }^{1,2}$, \\ DANIELA BARTOS ${ }^{1,2}$, ELISABETA BADILA ${ }^{1,2}$ \\ ${ }^{1}$ Internal Medicine Department, "Floreasca” Emergency Clinical Hospital, Bucharest, Romania \\ ${ }^{2 “ " C a r o l ~ D a v i l a " ~ U n i v e r s i t y ~ o f ~ M e d i c i n e ~ a n d ~ P h a r m a c y, ~ B u c h a r e s t, ~ R o m a n i a ~}$
}

\begin{abstract}
Background. The Roma population has a high prevalence of cardiovascular risk factors, higher mortality, and shorter life expectancy. It is found in the largest number in Romania, but published data are still scarce here. We studied cardiovascular risk factors and disease along with target organ damage on a population of Roma inhabitants from Bucharest, Romania.

Methods. This cross-sectional study enrolled 806 Roma subjects (18-83 years), in a communitybased participatory research manner. Demographics included anthropometric data, a questionnaire on social status, education, medical history, and health deleterious behaviors. Medical evaluation included clinical examination, blood pressure, ankle-brachial index, pulse wave velocity measurements, blood tests (complete blood count, lipid profile, glucose, creatinine, uric acid), dip-stick microalbuminuria, dilated fundoscopy, ECG, and echocardiography.

Results. Prevalence of all cardiovascular risk factors was high, peaking in abnormal lipid metabolism (82.13\%), heavy smoking (63.02\% including ex-smokers) and obesity (50.99\%). The first and the latter were actually similar to the general population in Romania. Almost half of subjects were at high or very high risk for fatal cardiovascular disease.

Conclusions. The study shows that the Roma population in a more affluent region in Romania shares a similarly high cardiovascular burden to their surrounding community.
\end{abstract}

Key words: cardiovascular risk factors; gypsy; Roma population.

\section{INTRODUCTION}

The largest minority of Europe, the Roma population, resides in the largest number in Romania, with a an estimated community of 1,850,000 members [1]. Most initial medical studies on Roma subjects were genetics-related as they often suffer from founder disorders due to frequent consanguinity marriages [2]. The "Decade of Roma Inclusion" initiative [3] developed concomitantly to the adherence to the European Union of countries with large Roma minorities (2005-2015). This led to an increased interest and awareness of Roma issues and larger data on determinants of health in this subgroup [4, 5]. Evidence gathered on worse selfreported health [6-8], chronic illness [9-11], and mortality $[5,12,13]$. Large disaggregated data on mortality by Roma ethnicity is scarce, but evidence builds up to show a ten years shorter life expectancy than their surrounding community [14]. For the past two decades research of Roma health shifted focus from genetic disorders and communicable diseases to chronic illness and risk factors as determinants of mortality [15]. In search of a causality for higher mortality, we conducted a study to assess the prevalence of cardiovascular (CV) risk factors and target organ damage (TOD) in a population of Roma inhabitants from Romania.

\section{MATERIAL AND METHODS}

\section{Procedure}

This cross-sectional study was conducted in two phases, in the autumns of 2012 and 2013 in Bucharest, Romania, as part of a socially-oriented project to facilitate medical services among Roma ethnics, with the support of a nationally active nongovernmental organization in dealing with the Roma issue. Their representatives informed and invited the community to participate. A questionnaire and an algorithm for medical evaluation were developed by the medical team. Better funding allowed a more extensive evaluation during the second phase. Written fully informed consent for the study was obtained from all participants. The study was approved by the local Ethics Committee. 


\section{Study sample}

The studied population consisted of adult Roma residing in the two districts of Bucharest with the largest proportion of Roma minority according to the 2011 Census (District 5, 6990 Roma ethnics, or
$2.57 \%$ of its population, and, District 2, 5639 Roma ethnics, or $1.63 \%$ of its population) [16]. Data were collected on 400 subjects in 2012 and 406 subjects in 2013. Random sampling was unavailable, and recruitment was done by word-of-mouth and informational flyers distributed in the community.

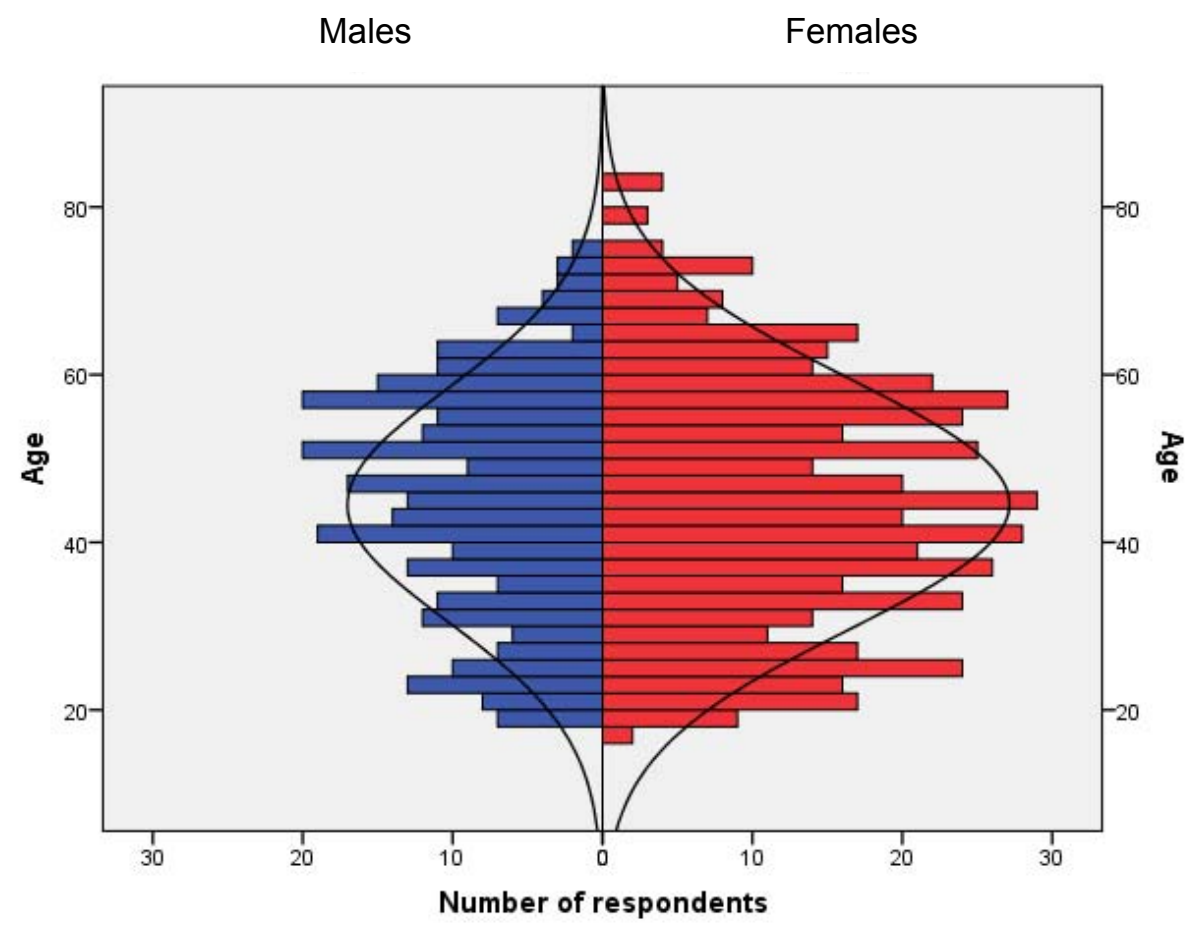

Figure 1. Age distribution by gender in the Roma population.

\section{Evaluation process}

The evaluation algorithm started with anthropologic measures and surveyor-assisted completion of the questionnaire. This was fully developed by the medical team, covering information on age, level of education, civil status, behaviors regarding smoking, alcohol consumption, physical exercise, salt intake, and personal and family medical history focusing on CV risk factors and disease (diagnostic, treatment, and control), namely arterial hypertension, diabetes mellitus, and dyslipidemia. During the second year, the questionnaire was updated with detailed evaluation of health services, health care expenditure, and living conditions. Afterwards, $8 \mathrm{~h}$ fasting blood testing was carried out and included: complete blood count, total cholesterol (TC), HDL and LDL fractions, triglycerides (TGL), glucose, creatinine, uric acid, with additional dip-stick microalbuminuria in hypertensive and diabetic subjects during the second phase of the study. Further, medical evaluation included thorough medical history, clinical evaluation, ECG, blood pressure (BP) and ankle-brachial index (ABI) measurements, augmented in the second year with pulse wave velocity (PWV) measurements and fundoscopy. Blood pressure measurements were taken using aneroid sphyngmomanometers, in both arms, after 5 minutes of rest in the supine position. Ankle-brachial index was measured using a HiDop $300 \mathrm{CW}$ Pocket Doppler device, and PWV was measured using an oscillometric TensioMed Arteriograph device. Finally, echocardiography was carried out either on a Siemens Acuson SC2000 or a Philips HD7XE ultrasound machine, to evaluate chamber and wall dimensions, wall motion abnormalities, and left ventricle function. The complete file of each subject was evaluated by a second blinded medical doctor in order to better refine the diagnostics established, with focus on newly diagnosed hypertension cases. This diagnosis integrated information on the presence of TOD, and history of high BP readings on previous 
medical visits/measurements. Risk for fatal CV disease (CVD) was calculated according to the criteria of the 2016 European Guidelines on CV disease prevention [17], integrating SCORE risk (chart for high risk regions of Europe) and comorbidities. Diagnostic criteria used for $\mathrm{CV}$ risk factors and comorbidities are shown in Table 1.

\section{Statistical analysis}

Statistical analysis was performed using IBM SPSS Statistics v23 at a significance level $\leq 0.05$. Categorical variables are presented as counts and percentages, and continuous variables are presented either as the mean values ( \pm standard deviation), or as median (interquartile range). Between-group comparisons were made using a non-parametric test (Mann-Whitney U), when comparing groups of unequal variances or with non-normal distribution, or chi-square $\chi^{2}$ for categorical variables. Logistic regression using enter method was performed to identify relationships between socioeconomic factors, $\mathrm{CV}$ risk factors, and total CVD risk. The dependent variable, 10 year risk of fatal CVD was dichotomized in either low and moderate risk, or high and very high risk.

Table 1

Diagnostic criteria used in the study

\begin{tabular}{|c|c|}
\hline Risk factor/Comorbidity & Definition/cut-off point \\
\hline \multicolumn{2}{|l|}{ Abnormal lipid profile $^{1}$} \\
\hline \multirow{4}{*}{ Newly diagnosed } & Total cholesterol $>190 \mathrm{mg} / \mathrm{dL}$, and/or \\
\hline & LDL cholesterol $>115 \mathrm{mg} / \mathrm{dL}$, and/or \\
\hline & HDL cholesterol: men $<40 \mathrm{mg} / \mathrm{dL}$, women $<46 \mathrm{mg} / \mathrm{dL}$, and/or \\
\hline & Triglycerides $>150 \mathrm{mg} / \mathrm{dL}$ \\
\hline Known dyslipidemia & Previously diagnosed \\
\hline Diabetes mellitus & Previously diagnosed diabetes mellitus \\
\hline Newly diagnosed & Fasting glucose $>126 \mathrm{mg} / \mathrm{dl}$ \\
\hline Hyperglycemia $^{2}$ & Fasting plasma glucose $102-125 \mathrm{mg} / \mathrm{dL}$ in non-diabetic subjects \\
\hline Hyperuricemia & Serum uric acid $>7 \mathrm{mg} / \mathrm{dL}$ \\
\hline \multicolumn{2}{|l|}{ Hypertension } \\
\hline Newly diagnosed & $\mathrm{BP}>140 / 90 \mathrm{mmHg}$ at medical evaluation \\
\hline Controlled & $\begin{array}{l}\text { Previously diagnosed hypertension with } \mathrm{BP}<140 / 90 \mathrm{mmHg} \text { on } \mathrm{BP} \text { lowering medication in those } \\
\text { having taken their medication during the past two weeks }\end{array}$ \\
\hline Obesity & $\mathrm{BMI} \geq 30 \mathrm{~kg} / \mathrm{m}^{2}\left(\mathrm{height}^{2}\right)$ \\
\hline Abdominal obesity & Waist circumference: men $\geq 102 \mathrm{~cm}$; women $\geq 88 \mathrm{~cm}$ \\
\hline $\begin{array}{l}\text { Family history of established } \\
\text { CVD }\end{array}$ & $\begin{array}{l}\text { History of hypertension, heart failure, myocardial infarction, stroke or death due to CV disease in at } \\
\text { least one first degree relative }\end{array}$ \\
\hline $\begin{array}{l}\text { Moderate to severe renal } \\
\text { impairment }\end{array}$ & Estimated glomerular filtration rate (CKD-EPI equation) $<60 \mathrm{~mL} / \mathrm{min}$ \\
\hline Microalbuminuria & Positive urinary protein by dipstick test \\
\hline Hypertensive retinopathy & Arteriosclerosis, arteriovenous nicking, retinal hemorrhage, remodeling and microaneurysms, exudates \\
\hline Smoking & Active smoking of at least one cigarette per day \\
\hline
\end{tabular}

\section{RESULTS}

\section{Demographic profile}

The population included adults aged 18-83 years (average age $44.54 \pm 14.57$, males $36.8 \%$ ). Baseline characteristics are displayed in Table 2, and age distribution in Graph 1. In this sample, $37.34 \%$ (301 subjects) were young adults (age < 40 years), $54.46 \%$ (439 subjects) were middle-aged (40-64 years) and only $8.18 \%$ (66 subjects) aged $\geq$ 65 years.
More than half were either married (51.24\%) or living with a partner $(8.19 \%)$, a quarter were separated or single $(26.18 \%)$, and $11.29 \%$ were widowed, a status more frequent among women $(\mathrm{p}<0.001)$.

The population had spent on average 9.07 $(8,12)$ years in school, $38.8 \%$ had finished secondary school, $24.2 \%$ had finished primary school, while $3.6 \%$ were illiterate. Females were less educated, having spent less time in school $(8.79(7,12)$ years vs. $9.57(8,12)$ years, p 0.004), and were more frequently illiterate ( $\mathrm{p} 0.026)$. 
Unemployment rate, evaluated in the second phase of the project, had a prevalence of $53.44 \%$, women finding themselves more frequently with such status $(\mathrm{p}<0.012)$. Another $31.52 \%$ reported job stability, more frequently males $(\mathrm{p}<0.005)$. There was an additional $15.02 \%$ retirement rate, without gender differences. Lower levels of education were associated with unemployment $(\mathrm{p}<0.001)$.

According to questionnaire results from the second phase, last medical evaluation and last routine blood tests evaluation benefited by subjects was on average $21.2(6.06,33.87)$ months, respectively, $21.43(7.95,46)$ months prior to study date. Up to $4.19 \%$ of subjects had never seen a doctor before, and $8.37 \%$ had never taken a blood test.
As much as $40.88 \%$ of subjects had no medical insurance, but $75.6 \%$ had a family doctor, and in $79.8 \%$ of these cases their relationship was good or very good. By 2017 , almost half of those uninsured $(45.78 \%$ ) had changed their status, but only $12.04 \%$ had registered with a family physician, and have done so at least 6 months after the medical encounter of the herein discussed projects. Higher levels of education were associated with a higher probability to be medically insured $(\mathrm{p}<0.001)$.

In reference to living conditions, also assessed in the second phase of the project, number of rooms per person was on average $1.5(1,2)$, with an overcrowding rate (including dependent children) of $59.6 \%$.

Table 2

Total population characteristics

\begin{tabular}{|c|c|c|c|c|}
\hline & $\begin{array}{c}\text { Total } \\
\mathrm{n}=806\end{array}$ & $\begin{array}{c}\text { Male } \\
\mathrm{n}=297\end{array}$ & $\begin{array}{c}\text { Female } \\
\mathrm{n}=509\end{array}$ & $\begin{array}{l}\text { p value } \\
M v s . F\end{array}$ \\
\hline No. subjects project 1 & 400 & 147 & 253 & - \\
\hline No. subjects project 2 & 406 & 150 & 256 & - \\
\hline Average age & $44.53 \pm 14.58$ & $44.46 \pm 13.93$ & $44.58 \pm 14.96$ & ns \\
\hline BMI $\left(\mathrm{kg} / \mathrm{m}^{2}\right)$ & $\begin{array}{c}26.99 \\
(22.76,31.62)\end{array}$ & $\begin{array}{c}27.14 \\
(23.49,31.16) \\
\end{array}$ & $\begin{array}{c}26.77 \\
(21.94,32)\end{array}$ & ns \\
\hline Subjects with moderate to severe renal impairment & $30(3.72 \%)$ & $6(2.02 \%)$ & $24(4.71 \%)$ & ns \\
\hline Subjects with $\mathrm{ABI}<0.9$ & $319(39.57 \%)$ & $104(35.02 \%)$ & $215(42.24 \%)$ & 0.043 \\
\hline $\begin{array}{l}\text { Subjects with increased arterial stiffness (PWV }>10 \mathrm{~m} / \mathrm{s} \text { ) } \\
\text { (measured only in those from the second project) }\end{array}$ & $130(32.01 \%)$ & $28(18.66 \%)$ & $102(39.84 \%)$ & $<0.001$ \\
\hline Pulse pressure $(\mathrm{mmHg})$ & $50(40,60)$ & $50(40,60)$ & $50(40,60)$ & ns \\
\hline Subjects aged $\geq 65$ years with pulse pressure $\geq 60 \mathrm{mmHg}$ & $47(71.21 \%)$ & $17(89.5 \%)$ & $30(63.8 \%)$ & 0.037 \\
\hline $\begin{array}{l}\text { Arterial hypertension } \\
\text { Newly diagnosed } \\
\text { Previously diagnosed } \\
\text { Uncontrolled }\end{array}$ & $\begin{array}{c}271(33.62 \%) \\
64(23.61 \%) \\
207(76.38 \%) \\
114(55.07 \%)\end{array}$ & $\begin{array}{l}98(32.99 \%) \\
35(35.71 \%) \\
63(64.28 \%) \\
32(50.79 \%)\end{array}$ & $\begin{array}{c}173(33.98 \%) \\
29(16.76 \%) \\
144(83.23 \%) \\
82(47.39 \%)\end{array}$ & $\begin{array}{c}\mathrm{ns} \\
0.001 \\
0.001 \\
0.018\end{array}$ \\
\hline Abnormal lipid profile & $445(55.21 \%)$ & $179(60.26 \%)$ & $266(52.25 \%)$ & $\mathrm{ns}$ \\
\hline $\begin{array}{l}\text { Previously diagnosed dyslipidemia } \\
\text { Uncontrolled dyslipidemia }\end{array}$ & $\begin{array}{c}217(26.92 \%) \\
172 / 217(79.26 \%)\end{array}$ & $\begin{array}{c}73(24.57 \%) \\
56 / 73(76.71 \%)\end{array}$ & $\begin{array}{c}144(28.29 \%) \\
116 / 144(80.55 \%)\end{array}$ & $\begin{array}{l}\mathrm{ns} \\
\mathrm{ns}\end{array}$ \\
\hline High total cholesterol & $435(53.97 \%)$ & $164(55.21 \%)$ & $271(53.24 \%)$ & ns \\
\hline High LDL & $539(66.87 \%)$ & $204(68.68 \%)$ & $335(65.81 \%)$ & ns \\
\hline Low HDL & $183(22.7 \%)$ & $64(21.54 \%)$ & $119(23.37 \%)$ & ns \\
\hline High triglycerides & $254(31.51 \%)$ & $123(41.41 \%)$ & $131(25.73 \%)$ & ns \\
\hline Mixed dyslipidemia & $269(33.37 \%)$ & $119(40.06 \%)$ & $150(29.46 \%)$ & ns \\
\hline Diabetes mellitus & $122(15.13 \%)$ & $52(17.5 \%)$ & $70(13.75 \%)$ & ns \\
\hline Previously diagnosed & $92 / 122(75.40 \%)$ & $37 / 52(71.15 \%)$ & $55 / 70(78.57 \%)$ & ns \\
\hline Hyperglycemia (in non-diabetics) & $84(10.42 \%)$ & $45(15.15 \%)$ & $39(7.66 \%)$ & 0.001 \\
\hline Hyperuricemia & $106(13.15 \%)$ & $65(21.88 \%)$ & $41(8.05 \%)$ & $<0.001$ \\
\hline Obesity & $266(33 \%)$ & $94(31.64 \%)$ & $174(34.18 \%)$ & ns \\
\hline Abdominal obesity & $411(50.99 \%)$ & $116(39.05 \%)$ & $295(57.96 \%)$ & $<0.001$ \\
\hline \multicolumn{5}{|l|}{ Smoking } \\
\hline Never & 299 (36.97\%) & $86(28.95 \%)$ & $213(41.84 \%)$ & ns \\
\hline Active smoking & $343(42.55 \%)$ & $135(45.45 \%)$ & $208(40.86 \%)$ & ns \\
\hline Ex-smoker & $164(20.34 \%)$ & $76(25.58 \%)$ & $88(17.28 \%)$ & 0.005 \\
\hline Average no. cigarettes/day (including ex-smokers) & $20(10-20)$ & $20(10,20)$ & $15(10,20)$ & $<0.001$ \\
\hline Average no. years (including ex-smokers) & $20(12.25,30)$ & $20(15,35)$ & $20(10,29)$ & 0.002 \\
\hline Average no. pack-years (including ex-smokers) & $15(7.5,30)$ & $20(10,34)$ & $12.5(6.62,24.15)$ & $<0.001$ \\
\hline Starting age (including ex-smokers) & $18(15,21)$ & $18(15,20)$ & $18(15.5,22)$ & ns \\
\hline
\end{tabular}




\section{Cardiovascular risk factors}

An abnormal lipid profile (including controlled previously diagnosed dyslipidemics) was the most frequent $\mathrm{CV}$ risk factor in the population $(82.13 \%)$, followed by smoking $(63.02 \%$ when considering both ex-smokers and active smokers), a sedentary life style (60.91\% reported mild-moderate household activity and similar, or no physical exercise at all), and abdominal obesity (50.99\%).

In 217 subjects $(26.92 \%)$ a diagnosis of dyslipidemia had already been made, but $42.39 \%$ showed a mixed dyslipidemia profile sharing high LDL levels with either low HDL and/or high TGL levels, and $12.9 \%$ sharing all three abnormalities. Only $40.55 \%$ of previously known dyslipidemics were on statin therapy, and among these abnormal levels of the above parameters were still seen in $70.45 \%$ of cases. Apart from these, another 445 subjects (55.21\%) were found to have an abnormal lipid profile (Table 2).

The studied population showed high smoking rates with $42.55 \%$ active smokers, and another $20.34 \%$ reported having quit smoking for over one year. In this population, females appear to smoke less cigarettes per day on average than males $(\mathrm{p}<$ 0.001 ), and males report longer periods of active smoking $(\mathrm{p}<0.002)$, thus leading to a higher nicotinic burden, measured as pack-years, on the latter $(p<0.001)$. Higher levels of education were inversely associated with a lower prevalence of smoking ( $p<0.001)$.

The prevalence of obesity and abdominal obesity increased proportionally with the decrease in levels of physical activity $(\mathrm{p}<0.001)$. Abdominal obesity was more frequently encountered in females $(p<0.001)$, significantly more sedentary than their male counterparts $(\mathrm{p}<0.001)$. Both body mass index and waist circumference were weakly correlated with dyslipidemia $\left(\mathrm{r}^{2} 0.09, \mathrm{p}<0.01\right.$, respectively $\left.r^{2} 0.10, p<0.01\right)$, hypertension $\left(r^{2} 0.15, p<0.01\right.$, respectively $\left.\mathrm{r}^{2} 0.14, \mathrm{p}<0.01\right)$, and diabetes $\left(\mathrm{r}^{2} 0.10, \mathrm{p}<0.01\right.$, respectively $\left.\mathrm{r}^{2} 0.11, \mathrm{p}<0.01\right)$.

The prevalence of arterial hypertension in the entire population sample was of $33.62 \%$ (271 subjects), with no gender differences, of which 207 subjects (76.38\%) were previously diagnosed hypertensives, with a control rate of $44.39 \%$.
When defining TOD as the presence of either of left ventricle hypertrophies, pulse pressure $\geq$ $60 \mathrm{mmHg}$ in those $\geq 65$ years old, PWV $>10 \mathrm{~m} / \mathrm{s}$, $\mathrm{ABI}<0.9$, moderate to severe renal impairment, presence of microalbuminuria, or hypertensive retinopathy, $90.03 \%$ of hypertensives were affected, males more frequently than females $(p<0.044)$. There was no difference in such composite variable between previously diagnosed and newly diagnosed hypertensives, but it was less frequent in those with controlled hypertension ( $83.9 \%$ vs. 93.3\%, p < 0.014).

As much as $60.54 \%$ of all subjects and $62.36 \%$ of hypertensive subjects reported family history of CVD at younger ages (females $<65$ years, males $<55$ years).

Diabetes mellitus was recorded in $15.13 \%$ of the entire sample population, but it had been previously diagnosed in most cases $(75.40 \%)$; TOD, microalbuminuria and diabetic retinopathy were present in $21.42 \%$, respectively $12.5 \%$ of diabetic subjects. Hyperglycemia in non-diabetics was more frequent in males $(p<0.001)$, and it was not associated with the presence of microalbuminuria or retinopathy.

When assessing 10 year risk of fatal CVD in those 40 years and older (481 subjects), close to half $(46.57 \%)$ had high/very high risk, male gender being associated with higher risk $(p<0.001)$. In $60.26 \%$ of cases the high/very high risk classification was due to the presence of comorbidities or risk factors which overrun the SCORE risk. For the remaining, SCORE risk was low, with a median of $1(0,2)$, again higher in males $(p<0.001)$.

Higher levels of education were associated with less smoking ( $\mathrm{p}$ 0.034) and less hypertension (p 0.001), and even with lower CVD risk in the $\geq$ 40 years old population (p 0.003). Education was also associated with living conditions, a larger number of years in school being associated to a lower number of persons living in the same room $\left(p<0.001, r^{2} 0.84\right)$. Better living conditions were also associated with more dyslipidemia $(\mathrm{p}<0.05)$, diabetes $(\mathrm{p}<0.003)$, hypertension $(\mathrm{p}<0.001)$, obesity $(p<0.002)$ and abdominal obesity $(p<0.004)$. But on logistic regression including $\mathrm{CV}$ risk factors, socio-economic factors (number of persons per room, number of years in school, unemployed vs. employed status, and single $v s$. married status) were not independently associated with higher 10 year risk of fatal CVD (Table 3). 
Table 3

Factors associated with high and very high cardiovascular risk in adults $\geq 40$ years (Logistic regression)

\begin{tabular}{|lcccc|}
\hline Variables & $\mathrm{p}$ value & OR & \multicolumn{2}{c|}{$95 \%$ C.I. } \\
\hline Person per room & 0.521 & 0.965 & 0.867 & 1.075 \\
\hline Number years of education & 0.087 & 0.707 & 0.475 & 1.052 \\
\hline Unemployed status & 0.527 & 1.280 & 0.596 & 2.748 \\
\hline Being single & 0.805 & 0.910 & 0.430 & 1.925 \\
\hline Ankle-brachial index & 0.456 & 0.459 & 0.059 & 3.555 \\
\hline Uric acid $(\mathrm{mg} / \mathrm{dL})$ & 0.073 & 1.256 & 0.979 & 1.612 \\
\hline Body mass index $\left(\mathrm{kg} / \mathrm{m}^{2}\right)$ & 0.008 & 0.862 & 0.773 & 0.962 \\
\hline Waist circumference $(\mathrm{cm})$ & 0.002 & 1.081 & 1.029 & 1.135 \\
\hline Pulse pressure $(\mathrm{mmHg})$ & 0.000 & 1.068 & 1.037 & 1.099 \\
\hline Pulse wave velocity $(\mathrm{m} / \mathrm{s})$ & 0.001 & 1.305 & 1.114 & 1.528 \\
\hline
\end{tabular}

\section{DISCUSSION}

\section{Demographic profile}

This paper is a descriptive cross-sectional study providing a snapshot of Roma population health status focusing on $\mathrm{CV}$ risk factors and diseases. The convenience sample covered 5\% in 2012 and, respectively, $7 \%$ in 2013 of the local Roma minority. Its demographic characteristics are different from those of segregated communities. From a demographical standpoint, the sample can be characterized in terms of age distribution, urban origin, civil status, housing conditions, education level, and activity status (employment/unemployment, retirement rate).

The sample included subjects of urban origin, living in the capital city of Romania, details which may influence the degree of integration in the community around. In such metropolitan areas there is an increased availability of social, educational and medical services which positively influence living conditions and outcomes in all groups.

The age distribution of the Roma population has been described in literature, the most accurate recent depiction of it showing an age pyramid taking the expansive model shape of a young developing population with high fertility rates and lower life expectancies [12]. The scarce evidence on mortality in adult Roma underlines higher risk of all-cause death, irrespective of socioeconomic status, modeling the population distribution [5]. The latest census in Romania in 2011 confirms this pattern, with $42 \%$ of Roma citizens being $<20$ years, 33\% between 20-39 years, $21 \%$ in the $40-64$ years group, and only $4 \% \geq 65$ years [16]. This model is reversed from that seen in European countries facing the continuous trend of ageing populations. In our study, the majority of subjects were middle-aged adults, while only a very small percentage were old subjects, confirming the pattern of a young population with few elders.

According to the mentioned census, $48.73 \%$ vs. $29.63 \%$ of the non-Roma vs. Roma population are married. The first rate is closer to the one reported in our study (51.24\%). Similarly, 9.61\% vs. $4.21 \%$ of the non-Roma vs. Roma population was widowed, the first being closer to that of our studied sample (11.29\%).

Poor housing conditions are frequently found in Roma neighborhoods and the present study assessed them through two measures - the segregated vs. integrated environment and the overcrowding rate. All subjects came from an integrated environment, living in mixed neighborhoods of the capital city, with a slightly higher average number of rooms per person than the national average during the study time frame (1.5 vs. 1), but an overcrowding rate lower than the national average in $2013(59.6 \%$ vs. $69 \%$ ).

In terms of education levels, in Romania, $20.2 \%$ of the Roma are illiterate, $34.17 \%$ have finished primary school, and most (44.71\%) have finished secondary school (with much lower percentages of higher education levels), as opposed to $2.53 \%, 13.64 \%$, and respectively, $54.78 \%$ of nonRoma inhabitants. Therefore, education-wise our sample is rather similar to the non-Roma population.

Unemployment rate (including housewives and those in the care of others) was reported in census at $20.53 \%$ vs. $56.35 \%$ in non-Roma $v s$. Roma inhabitants, while in our population it was observed at a very high rate, similar to the national Roma average. Retirement rate was however closer to that of the non-Roma $(21.70 \%)$ than Roma population $(5.6 \%)$.

Considering this data, the demographic profile of our population resembles more to the general non-Roma population, suggesting a high level of 
integration in the local culture, and a tendency to change and share social practices and resources. Exception comes from the high unemployment rate, especially in women, which may reflect a personal choice of a culture in which males are seen as the main income providers, while females have a primary role in caring for the household and children [18]. The similarity to the surrounding community can therefore act as a control of environmental factors for better comparison with the general non-Roma population.

Primary care is free for all residents in Romania and this includes emergency care and having a family physician. However, preventive and secondary care are not accessible in the absence of medical insurance coverage. A study carried out in 12 Central and Eastern Europe countries focusing on Roma health issues found a significant gap between Roma and non-Roma residents in health care accessibility, with insurance coverages ranging from $2.8 \%$ to $67.7 \%$, Romania reporting a $49.3 \%$ coverage among Roma [19]. As much as two thirds of subjects from the second phase of the project had a family physician and most reported a good patient-doctor relationship, however this did not appear to influence the low insurance coverage, similar to the above mentioned study. It may be hypothesized that despite the availability of medical facilities, the Roma fail to consider medical insurance until the occurrence of significant health issues which require emergency admission to hospital, a moment when continuing medical care beyond stabilizing the patient requires an insured status.

\section{Cardiovascular profile}

Dyslipidemia peaked in prevalence among CV risk factors, with high LDL levels as the most frequent lipid abnormality. Lipid disorders are rarely assessed in the general population as their role as a marker and therapeutic target in CV pathology is related to global CV risk [20]. However, our results show an alarmingly high prevalence of lipid abnormalities, with poor control of target parameters even in those already using statins. Higher levels of LDL, TC and TGL with lower levels of HDL have been reported in Roma vs. non-Roma [21,22]. In the USA lipid abnormalities were reported in 53\% of adults [23]. In Europe, the NATPOL survey reported a $61.1 \%$ prevalence of hypercholesterolemia among adults [24], while the more recent PREDATORR study showed an alarming prevalence of lipid disorders in the Romanian adult population of $81 \%$ [25]. Our results therefore are concordant with these latter findings, placing our population at high, but similar prevalence of lipid disorders to their surrounding community.

Smoking prevalence in Romania was estimated according to a WHO report by the end of 2016 at $26.7 \%$ of the population, twice in males than in females (37.4\% vs. 16.7\%) [26]. This pattern of higher nicotinic burden in males is seen in our sample as well, but the $42.55 \%$ prevalence of active smokers plus the extra $20.34 \%$ ex-smokers are consistent with other findings showing that Roma populations have significantly higher prevalence of smoking, when compared with their local communities, of up $72 \%$ [27]. This is ever more disturbing considering smoking cessation strategies were shown to be less effective in Roma, who, in the context of a fatalist culture, do not see this behavior as deleterious for health [28]. Reluctance to quit is retained in pregnant females, as continued smoking was reported at $89.3 \%$ even after learning of pregnancy [29]. In some aspects, the poor health of ethnic populations may be influenced by socioeconomic factors such as low income, low education, and low employment rates [30]. However, when considering smoking in Roma ethnics, it was shown that the lower socioeconomic status cannot fully mediate the disparities with non-Roma inhabitants [31]. This left room for the search for a genetic predisposition, which was recently shown not to play a significant role in this risk behavior in Roma ethnics, thus suggesting that focus should be placed on cultural and environmental factors [32].

Obesity and abdominal obesity prevalence was high, without gender differences in our study. These findings are consistent among different countries, as obesity has been reported as more frequent in Roma populations across Europe [33-35]. In a study conducted in 19 European countries educational inequalities were associated with different trends in weight gain, with obesity being more likely seen in lower educational groups [36]. However, as in the case of smoking, differences between Roma and non-Roma subjects in terms of nutrition habits, like consumption of fruits and vegetables and type of fat used for cooking, as factors contributing to the development of obesity, were not explained by socioeconomics alone [31]. A study conducted in South Bohemia on Roma inhabitants showed their frequent engage in unhealthy irregular eating schedules and excessive consumption of fast food [37]. The cultural background placing the Roma population among those with highest rates of obesity is reflected by a 
study carried out in Spain which showed that the subjects failed to correctly perceive their body-size and see themselves as obese or overweight [38]. Lastly, the Roma population may have a genetic predisposition towards obesity when faced with nutritional transitions as seen in other special populations as the US Pima-Indians or the Hawaiian Samoans. In Roma people, their history of nomadic life with frequent food shortages may have led to an evolutionary survival trait to efficiently store energy, now maladaptive and predisposing to obesity [38]. Indeed, Zeljko et al. found an association between the $\varepsilon 2$ allele of apolipoprotein $\mathrm{E}$ gene polymorphism and obesity indicators in a Roma sample from rural Croatia, proving a genetic component in their development of obesity [39]. The presence of significant chronic diseases and comorbidities limits daily activities, and in the case of Roma, having worse health at younger ages, it may add to the other factors predisposing to obesity. However, comparing our findings with the results of the PREDATORR study, this Roma population had similar obesity (31.9\% Romanian vs. 33\% Roma, $\mathrm{p}>0.05$ ), and actually less abdominal obesity (73.9\% Romanian vs. 50.99\% Roma people, p < $0.001)$. It should be noted that criteria used to define abdominal obesity were lower than in the current study (waist circumference $>80 \mathrm{~cm}$ in females and $>94 \mathrm{~cm}$ in males), but even so, in our study prevalence remains significantly lower $(p<0.01)$.

Several studies have addressed the higher CV risk in the Roma population, assessing individual $\mathrm{CV}$ risk factors $[6,21]$. Beyond this lies the global risk of each individual, and the data presented above proves that this subgroup is not only burdened by the high prevalence of risk factors, but is a population in which almost one of two adults has individual high or very high risk of fatal CVD during the 10 years to come. Furthermore, this risk was in most cases a consequence of co-existing comorbidities beyond the SCORE risk, suggesting that there is a great chance the average adult Roma, especially if male, has established CVD and will soon develop a fatal event.

The role of socioeconomic factors in disparities in health is controversial when comparing ethnic groups with the general population. Even though health outcomes were shown to be generally influenced by socioeconomic factors [9, 40], our findings also suggest that they act as covariates that influence CV risk factors without having an independent association to higher risk for CV disease. The relation between better living conditions and higher disease burden is noteworthy as it may show how improving social status in the Roma does not equate better health outcomes, in an epidemiological trend of westernization of lifestyle and acquisition of lifestyle related CV risk factors. Higher education did have a positive influence on CV risk factors and was close to emerging as independently associated with lower CVD risk ( $p$ 0.087). Thus it may be able to moderate these deleterious effects of westernization.

\section{Limitations}

The first limitation of our study is the lack of a control group - a direct comparator of non-Roma residents. However, the availability of large data collected from a high number of participants allowed the comparison with that from national epidemiologic studies.

The studied population was a convenience sample, therefore results cannot be extrapolated to the entire Roma population, either in Romania, or in the region. The difficulties of random sampling stem from the separation between declared and identified ethnicity which impairs accurate reporting of their numbers, leading to the use of estimates in official documentation [41].

Another relevant limitation originates from the self-reported nature of personal or family medical history. To counteract this, significant caution was applied in the case of absent medical records to sustain a self-reported diagnosis and the thorough history taking, medical evaluation, and integration of available data by the first and second observer aimed to balance the inherent limitations, still widely encountered in many scenarios of current clinical practice.

\section{CONCLUSIONS}

Our study shows that a Roma population sharing similar demographic characteristics to its surrounding community retains a profile of high $\mathrm{CV}$ risk, evident not only on a population level but also on an individual one. Socioeconomic status was correlated with the presence of CV risk factors, but it was not independently associated with total higher CV risk in this population.

Funding: Funding for the SUPORT projects was insured by grants from The Romanian Government National Agency for Roma in 2012 and 2013.

Conflict of interest: The authors have no conflict of interest to declare. 
Introducere. Populația Romă este caracterizată de o prevalență mare a factorilor de risc cardiovascular (FRCV), mortalitate crescută, şi speranță de viață redusă. Cel mai mare număr de persoane de etnie Romă se regăseşte în România, dar datele publicate aici sunt limitate. Studiul de față a evaluat FRCV, boala cardiovasculară şi afectarea de organ țintă într-o populație Romă din Bucureşti, România.

Metode. Acest studiu transversal a înrolat, într-o manieră participativă din partea comunității, 806 subiecți Romi adulți (18-83 ani). Datele demografice colectate au inclus măsurători antropometrice, un chestionar despre statutul civil, educație, istoric medical, şi comportamente dăunătoare pentru sănătate. Evaluarea medicală a inclus examen clinic, măsurători ale tensiunii arteriale, ale indicelui gleznă-braț, vitezei undei pulsului, teste de sânge (hemoleucogramă, profil lipidic, glicemie, creatinină, acid uric), microalbuminurie, fundoscopie, electrocardiografie, ecocardiografie.

Rezultate. Prevalența tuturor FRCV a fost crescută, cel mai frecvent întâlniți fiind profilul lipidic alterat (82.13\%), fumatul (63.02\% incluzând foşti fumători), şi obezitatea (50.99\%). Primul şi cel din urmă au avut prevalențe similare cu cele raportate pentru populația generală din România. Aproape jumătate din subiecți s-au aflat la risc înalt sau foarte înalt de boală cardiovasculară fatală.

Concluzii. Studiul arată că populația Romă dintr-o regiune dezvoltată din România are o încărcătură patologică cardiovasculară înaltă, dar similară în multe aspecte cu cea a comunității locale.

Correspondence to: Emma Weiss, MD, Internal Medicine Department, Emergency Clinical Hospital Bucharest, 8 Calea Floreasca, 014461, District 1, Bucharest, Romania, Telephone: +40 722628197

E-mail: emmaweissmd@gmail.com

\section{REFERENCES}

1. A. ORAV, At a glance. EU policy for Roma inclusion, Eur. Parliam. Res. Serv. (2016). http://www.europarl.europa.eu/thinktank/ en/document.html?reference=EPRS_ATA(2016)579094. Accessed December 2nd 2017.

2. L. KALAYDJIEVA, D. GRESHAM, F. CALAFELL, Genetic studies of the Roma (Gypsies): a review, BMC Med. Genet. 2001; 2(1):5.

3. Decade of Roma Inclusion 2005-2015. Decade Declaration., Open Soc. Roma Initiat. (2005). https://web.archive.org/web/ 20120605103704/http://www.romadecade.org/decade_declaration. Accessed December 2nd 2017.

4. C. BRÜGGEMANN, E. FRIEDMAN, E. FRIEDMĀN, The Decade of Roma Inclusion: Origins, Actors, and Legacies, Eur. Educ. 2017;4 9(1):1-9. doi:10.1080/10564934.2017.1290422.

5. B. COOK, G.F. WAYNE, A. VALENTINE, A. LESSIOS, E. YEH, Revisiting the evidence on health and health care disparities among the Roma: A systematic review 2003-2012, Int. J. Public Health. 2013; 58(6):885-911. doi:10.1007/s00038-013-0518-6.

6. T. JANEVIC, J. JANKOVIC, E. BRADLEY, Socioeconomic position, gender, and inequalities in self-rated health between Roma and non-Roma in Serbia, Int. J. Public Health. 2012; 57(1)49-55. doi:10.1007/s00038-011-0277-1.

7. P. CARRASCO-GARRIDO, A. LOPEZ DE ANDRES, V. HERNANDEZ BARRERA, I. JIMENEZ-TRUJILLO, R. JIMENEZGARCIA, Health status of Roma women in Spain, Eur. J. Public Health. 2010; 21(6):793-798. doi:10.1093/eurpub/ckq153.

8. C. MASSERIA, P. MLADOVSKY, C. HERNANDEZ-QUEVEDO, The socio-economic determinants of the health status of Roma in comparison with non-Roma in Bulgaria, Hungary and Romania, Eur. J. Public Health. 2010; 20(5)549-554. doi: 10.1093/eurpub/ckq102.

9. H.M. ZELJKO, T. ŠKARIĆ-JURIĆ, N.S. NARANČIĆ, A. BAREŠIĆ, Ž. TOMAS, M.Z. PETRANOVIĆ, et al., Age trends in prevalence of cardiovascular risk factors in Roma minority population of Croatia, Econ. Hum. Biol. 2013; 11(3):326-336. doi:10.1016/j.ehb.2012.02.007.

10. H. ZELJKO, T. SKARIĆ-JURIĆ, N.S. NARANCIC, M.P. SALIHOVIĆ, I.M. KLARIĆ, M. BARBALIĆ, et al., Traditional CVD risk factors and socio-economic deprivation in Roma minority population of Croatia, Coll. Antropol. 2008; 32(3):667-76.

11. M.Z. MOLNAR, R.M. LANGER, A. REMPORT, M.E. CZIRA, K. RAJCZY, K. KALANTAR-ZADEH, et al., Roma ethnicity and clinical outcomes in kidney transplant recipients, Int. Urol. Nephrol. 2012; 44(3):945-954. doi:10.1007/s11255-011-0088-6.

12. D. BOGDANOVIĆ, D. NIKIĆ, B. PETROVIĆ, B. KOCIĆ, J. JOVANOVIĆ, M. NIKOLIĆ, et al., Mortality of Roma population in Serbia, 2002-2005, Croat. Med. J. 2007; 48(5):720-6.

13. L.M. BLAGOJEVIĆ, D.C. BOGDANOVIĆ, S.J. JOVIĆ, Z.G. MILOŠEVIĆ, Z.Ć. DOLIĆANIN, Excess winter mortality of Roma population in Serbia, 1992-2007, Cent. Eur. J. Public Health. 2012; 20(2):135-138.

14. A. FLECHA, Healthier Lives for European Minority Groups: School and Health Care, Lessons from the Roma, Int. J. Environ. Res. Public Health. 2013; 10(8):3089-3111. doi:10.3390/ijerph10083089. 
15. M.E. FOLDES, A. COVACI, Research on Roma health and access to healthcare: state of the art and future challenges, Int. J. Public Health. 2012; 57(1):37-39. doi:10.1007/s00038-011-0312-2.

16. INSTITUTUL NATIONAL DE STATISTICA, Rezultate definitive ale Recensământului Populației şi al Locuințelor - 2011 , 2011. http://www.recensamantromania.ro. Accessed December 2nd 2017.

17. M.F. PIEPOLI, A. HOES, S. AGEWALL, C. ALBUS, C. BROTONS, A.L. CATAPANO, et al., 2016 European Guidelines on cardiovascular disease prevention in clinical practice, Eur. Heart J. 2016; 37(29):2315-2381. doi:10.1093/eurheartj/ehw106.

18. C.I. RAVNBØL, The Human Rights of Minority Women: Romani Women's Rights from a Perspective on International Human Rights Law and Politics, Int. J. Minor. Gr. Rights. 2010; 17(1):1-45. doi:10.1163/157181110X12595859744123.

19. C. KUHLBRANDT, K. FOOTMAN, B. RECHEL, M. MCKEE, An examination of Roma health insurance status in Central and Eastern Europe, Eur. J. Public Health. 2014; 24(5):707-712. doi:10.1093/eurpub/cku004.

20. A.L. CATAPANO, I. GRAHAM, G. DE BACKER, OLOVWIKLUND, M.J. CHAPMAN, H. DREXEL, et al., 2016 ESC/EAS Guidelines for the Management of Dyslipidaemias, Eur. Heart J. 2016; 37(39):2999-3058. doi:10.1093/eurheartj/ehw272.

21. B. VOZAROVA DE COURTEN, M. DE COURTEN, R.L. HANSON, A. ZAHORAKOVA, H.P. EGYENES, P.A. TATARANNI, et al., Higher prevalence of type 2 diabetes, metabolic syndrome and cardiovascular diseases in gypsies than in non-gypsies in Slovakia, Diabetes Res. Clin. Pract. 2003; 62(2):95-103. doi:10.1016/S0168-8227(03)00162-1.

22. M. KRAJCOVICOVA-KUDLACKOVA, P. BLAZICEK, V. SPUSTOVA, M. VALACHOVICOVA, E. GINTER, Cardiovascular risk factors in young Gypsy population, Bratisl. Lek. Listy. 2004; 105(7-8):256-9. http://www.ncbi.nlm.nih.gov/pubmed/ 15543846.

23. P.P. TOTH, D. POTTER, E.E. MING, Prevalence of lipid abnormalities in the United States: The National Health and Nutrition Examination Survey 2003-2006, J. Clin. Lipidol. 2012; 6(4):325-330. doi:10.1016/j.jacl.2012.05.002.

24. T. ZDROJEWSKI, B. SOLNICA, B. CYBULSKA, P. BANDOSZ, M. RUTKOWSKI, J. STOKWISZEWSKI, et al., Prevalence of lipid abnormalities in Poland. The NATPOL 2011 survey, Kardiol. Pol. 2016; 74(3):213-223. doi:10.5603/KP.2016.0029.

25. M. MOTA, E. MOTA, S. POPA, D. CATRINOIU, D. CHETA, M. GRAUR, et al., P.R.E.D.A.T.O.R.R. - Romanian National Study on the Prevalence of Diabetes, Prediabetes, Overweight and obesity, dyslipidemia, hyperuricemia and chronic kidney disease - Final results, Acta Diabetol. Rom. 2014; 40(1):24-26.

26. WHO, WHO report on the global tobacco epidemic 2017, 2017. http://www.who.int/tobacco/global_report/en/.

27. E. PAULIK, L. NAGYMAJTÉNYI, D. EASTERLING, T. ROGERS, Smoking behaviour and attitudes of Hungarian Roma and non-Roma population towards tobacco control policies, Int. J. Public Health. 2011; 56(5):485-491. doi:10.1007/s00038-0110252-x.

28. D. PETEK, D.R. PAVLIC, I. SVAB, D. LOLIĆ, Attitudes of Roma toward smoking: qualitative study in Slovenia., Croat. Med. J. 2006; 47(2):344-7.

29. [P. BALÁZS, I. RÁKÓCZI, A. GRENCZER, K.L. FOLEY, Risk factors of preterm birth and low birth weight babies among Roma and non-Roma mothers: A population-based study, Eur. J. Public Health. 2013; 23 (3):480-485. doi:10.1093/eurpub/ cks089.

30. W.W. DRESSLER, K.S. OTHS, C.C. GRAVLEE, Race and Ethnicity in Public Health Research: Models to Explain Health Disparities, Annu. Rev. Anthropol. 2005; 34(1):231-252. doi:10.1146/annurev.anthro.34.081804.120505.

31. Z. VOKÓ, P. CSÉPE, R. NÉMETH, K. KÓSA, Z. KÓSA, G. SZÉLEs, et al., Does socioeconomic status fully mediate the effect of ethnicity on the health of Roma people in Hungary?, J. Epidemiol. Community Health. 2009; 63(6):455-460. doi:10.1136/ jech.2008.079715.

32. S. FIATAL, R. TÓTH, Á. MORAVCSIK-KORNYICKI, Z. KÓSA, J. SANDOR, M. MKKEE, et al., High prevalence of smoking in the Roma population seems to have no genetic background, Nicotine Tob. Res. 2016; 18(12):2260-2267. doi: 10.1093/ntr/ntw161.

33. L. JOOSSENS, M. RAW, The Tobacco Control Scale 2016 in Europe, 2016. http://www.tobaccocontrolscale.org/wpcontent/uploads/2017/03/TCS-2016-in-Europe-COMPLETE-LoRes.pdf. Accessed December 2nd 2017.

34. S. DOLINSKA, M. KUDLACKOVA, E. GINTER, The prevalence of female obesity in the world and in the Slovak Gypsy women, Bratisl. Lek. Listy. 2007; 108(4-5):207-211.

35. D. PETRÁŠOVÁ, I. BERTKOVÁ, M. PETRÁŠOVÁ, E. HIJOVÁ, M. MAREKOVÁ, I. BABINSKÁ, et al., Biomarkers associated with obesity and overweight in the Roma population residing in Eastern Slovakia, Cent. Eur. J. Public Health. 2014; 22(suppl):S18-S21.

36. A.-J.R. ROSKAM, A.E. KUNST, H. VAN OYEN, S. DEMAREST, J. KLUMBIENE, E. REGIDOR, et al., Comparative appraisal of educational inequalities in overweight and obesity among adults in 19 European countries, Int. Journal Epidemiol. 2010; 39(2):392-404. doi:10.1093/ije/dyp329.

37. F. DOLAK, L. SEDOVA, D. NOVAKOVA, V. OLISAROVA, Approach to prevention of obesity of Roma population in the Region of South Bohemia with focus on selected eating behaviors., Neuroendocrinol. Lett. 2016; 37(suppl2):46-51.

38. A. POVEDA, M.E. IBANEZ, E. REBATO, Obesity and body size perceptions in a Spanish Roma population, Ann. Hum. Biol. 2014; 41(5):428-435. doi:10.3109/03014460.2014.882411.

39. H.M. ZELJKO, T. ŚKARIĆ-JURIĆ, N.S. NARANČIĆ, Ž. TOMAS, A. BAREŠIĆ, M.P. SALIHOVIĆ, et al., E2 allele of the Apolipoprotein e gene polymorphism is predictive for obesity status in Roma minority population of Croatia, Lipids Health Dis. 2011; 10:9. doi:10.1186/1476-511X-10-9.

40. A. ROSENGREN, S. HAWKEN, S. ÔUNPUU, P.K. SLIWA, M. ZUBAID, W.A. ALMAHMEED, et al., Association of psychosocial risk factors with risk of acute myocardial infarction in 11119 cases and 13648 controls from 52 countries (the INTERHEART study): Case-control study, Lancet. 2004; 364(9438):953-962. doi:10.1016/S0140-6736(04)17019-0.

41. EUROPEAN COMMISSION, Roma Health Report. Health status of the Roma population. Data collection in the Member States, 2014. doi:10.2772/33515. 